\title{
Information Management Aspect of Innovative Processes
}

\author{
Matjaz Mulej, Zdenka Zenko \\ University of Maribor, Slovenia \\ mule@unt-mb.si and zoenka.zenko@tech-transfer.si
}

\begin{abstract}
The so-called information society is one attribute of the modern innovative society. Due to complicatedness and complexity of the modern reality, it requires holistic, i.f. systematic thinking. On the other hand, systems thinking requires a rather holistic information at its basis. On such suppositions, authors discuss relation between information, innovation, and systems thinking, ad their implication for the information aspects of dealing with business and its management.
\end{abstract}

\section{The Selected Problem and Viewpoint}

The current reality is one of a growing complexity, and the current thinking is one of a growing narrow specialization. The gap between the two aspects of reality requires holism of action to be growing beyond the capacity of individual human beings. Creative co-operation may be a way out, but it requires capacity of:

- transdisciplinarity in values and approach, "My profession is essential for the topic under consideration, but it is not the only one essential."

- interdisciplinarity in method

"To be holistic enough, I have to cooperate with professionals from other disciplines, because they observe the same topic from different viewpoints. They disagree with me, therefore, and we are complementary and hence interdependent."

- and monodisciplinarity in knowledge

"Inside one single discipline, I have a chance to know enough, somehow, and to attain a sufficient depth of insight. Thus, others may need me, as I may need them."

It also requires communication to transfer information. Their perception and therefore action depends on information as well as on transformation of perception into information. The role of information, as compared to the one from the times of the 19th century industry, has

Material published as part of this proceedings, either on-line or in print, is copyrighted by the author with permission granted to the publisher of Informing Science for this printing. Permission to make digital or paper copy of part or all of these works for personal or classroom use is granted without fee provided that the copies are not made or distributed for profit or commercial advantage AND that copies 1) bear this notice in full and 2) give the full citation on the first page. It is permissible to abstract these works so long as credit is given. To copy in all other cases or to republish or to post on a server or to redistribute to lists requires specific permission from the author. become so important than many talk of the information age or even of the information society. On the other hand, information is a tool of innovation, and hence many talk of the innovation age and innovative society. Success depends on the level of holism, in both cases. The selected problem of this contribution is the relationship between systems thinking and the information management aspect of human work processes, especially the innovation related ones. And the selected viewpoint reads: how are informative processes and innovative processes interlinked, if conceived systemically?

\section{Chances for Systemic Thinking In the Information Society}

Let us accept the fact that there are as many teachers in the higher education, now, as they used to be in the primary education, a century ago, as Peter Drucker has reminded us a while ago. And let us conclude from this and other data about the 20th century, that the advanced part of the world has already entered the innovative society, which many tend to call the information society. It can be said to have shown up in the second half of the 20th century, which is also the period of creation of the biggest differences between parts of the world in which we are living. (See e.g.: Wood, 2000).

Let us summarise the controversies of the information society as follows. Information society is:

- Based on continuous innovating, along with a lot of traditionalism.

- Based on immense quantities of knowledge along with big lots of illiteracy.

- Based on networks of networks (supporting local, international, and global cooperation) along with lots of doors locked very precisely and other kinds of isolation. 


\section{Information Management Aspect of Innovative Processes}

- Based on democracy (in politics, economy, on shop floor, at home, locally) along with many dictators and jails.

- Based on entrepreneurship and progress along with growing joblessness.

- Based on world-wide peace along with lots of nuclear and other weapons.

- Based on lots of consideration of the natural environment along with the highest levels of pollution ever in history.

- Based on political and natural stability along with abuse of power and nature, which is expected to cause a serious lack of usable water and agricultural land in 30 -50 years ahead.

- Based on a very quick development along with leaving $80 \%$ of mankind aside.

- Based on big surpluses of supplies over demand along with a very poor life of $80 \%$ of mankind, billions starving etc.

- Etc. (see: UNESCO Courier, 1999 and 2000, Dyck, Mulej and coauthors, 1998; etc.)

Conclusion: the contemporary mankind has too many data and information available, and is hence unable to digest them all and in real time; therefore one-sidedness prevails like it used to in old times, although for different reasons. Therefore it may be no wonder that making of the innovative / information society is accompanied by making of the systems theory, as well as with its neglection in the daily practice. Very many find holism, which is required by the systems theory, too difficult for them to accept.

Thus, they are making a serious oversight: onesidedness, which is their selected alternative, leads to destruction of life. And this is a much more complex consequence than the application of systems theory for holism!

A second conclusion: mankind, or at least its vast majority need information about the real situation in order to accept systems thinking, which will make them able to understand and manage the information age / information society / innovative society better.

\section{The Role of Information in Systems Thinking and Systems Theory}

In the daily life, the word information tends to be used in many different contexts and contents with a lack of a clear definition (see: Rosicky, in Mulej et al., 2000). We can see the same reality concerning the word system. This is far from being the only attribute they may have in common.

\section{Definition of a System}

There are many different groups of definition of the term system. Three concepts make them quite different from each other:

1. "a system is a complex feature", i.e. it objectively exists and is made of a set of elements and a set of their relations;

2. "a system is a mathematical entity, an ordered set";

3. "a system is a mental and/or emotional information / message / picture of an object; the system and the object are both made of a set of elements and a set of their relations, but the system contains only a part of the object's really existing sets of elements and relations, or all of them": thus, the system exists as an information and may be equal to the object under consideration or to its part/s only.

It is easy to prove that any rather complex than simple object (feature, event, process) contains more properties than a single person can see, think of, think about, observe, manage. This fact is due to the natural limits of human capacities and to the resulting specialisation. Thus, the first definition is an oversimplification. The second above definition is fine inside the world of the mathematical theory, in terms of the real life and other disciplines it is an oversimplification as well: it has no contents. So is also the part of the third one saying that a system can be equal to the object under consideration. The conclusion is that in modern times no person can be holistic without cooperation with others who observe/research/manage the same object, but from different viewpoints. Their mutual difference makes these persons mutually needed and useful.

\section{Information}

Information is, first of all, to be delimited from the notions of data and message:

- Data exists when signs are ordered into a syntactic entity, such as a word.

- Message shows up when data is ascribed a meaning, thus receiving its semantic dimension.

- Information shows up when a message makes an impact by coming to be understood, accepted and causing an action. This is called the pragmatic dimension of information.

From such a definition, one can see that it is problematic to call the making and application of computers - informatics, even less so to let it monopolise the notion. The same 


\section{Mulej and Zenko}

would apply to ordering data in book keeping, in libraries etc. One can find something which all of them have in common, and so do all other features meeting the mathematical definition of a system:

- Information is an influential relation.

- There is no system, hence, without information.

- There is no entity, hence, without information.

- There is no order, hence, without information.

- Information is, hence, a natural phenomenon, which is not limited to humans and their relations and organizations.

- Information can be physical (e.g. in a stone, in a machine), biological (in a living cell, organ, organism), and/or human (in a group, organization, society, mankind).

- Information is, hence, an expression of interdependence in general.

- On the basis of these natural facts, the following conclusions are possible:

- Information can be a tool supportive of holism of thinking and working. But it is not necessarily so. It can support one-sidedness, too. The real impact depends on its contents, as well as on its perception by the addressee.

- Information can be linked with evolution (e.g. of a cell of an embryo, evolving into lever, of another cell of the same embryo evolving into the eye, etc.) and with development (of e.g. a society from a nomadic one to an postindustrial one over many steps in between).

- Information can be a tool against entropy, a tool of negentropy, because it induces order, evolution, development, holism, interdependence, relations etc. keeping or transforming an identity of an entity into another identity. But information can also be a tool supportive of entropy, if it supports one-sidedness rather than holism of impact, perception, thinking, and working.

- Information can also be a product of consciousness in terms of knowledge, data interpretation, learning and other experiencing, indeterminism and determinism. It can also be an input into consciousness and/or subconsciousness and/or preconsciousness.

- Information can be lacking and/or exceeding in terms of the information requirement.
- Information can be subject to individual subjective perception, understanding and interpretation of given data and messages.

The viewpoint in which the traditional sciences were specializing, was not the one of information - it was rather the one of energy and matter and their flows. The issue, e.g. was how much energy, food, etc. an embryo may need to become able to be born and survive. The issue from the viewpoint of cybernetics and systems theory is a different viewpoint: why will an embryo become a dog or an elephant rather than a tiger. The answer is: information. In this case in the structure of genes, as mankind has learned.

In business and economics, mankind used to come across a similar change of questions put from different viewpoints. As long as only the traditional question was asked, the basic process (the one of production of products and/or services, its supplies and sales) was found worth consideration. Cybernetics found the information and management processes to be (interdependent and interactive) preconditions of the basic process, a long time later on.

Conclusion: whatever one chooses to observe and/or manage, action and information show up as interdependent subsystems and partial systems of the same process. It is information that links all the steps of any process. It must, hence, be holistic in line with the law of requisite holism (Mulej, Kajzer, 1998; Rebernik, Mulej, 2000).

(The Mulej/Kajzer law of the requisite holism expresses the general experience that each and every person is entitled, in the real life, to define what is to be considered a/the suitable level of holism in his/her/their case. $\mathrm{He} / \mathrm{she} /$ they must, at the same time, accept responsibility for the consequences of their choice of the level of holism. E.g.: a general manager must think and act on a much broader basis than a worker on the assembly line. - This means that it is far from easy to define what is holistic, conceived and/or worked on in a holistic way. There are hardly any objective criteria concerning the systemic thinking, therefore. There are some ideals, but they tend to reflect their authors' experiences with their own objective environments and conditions.)

Therefore, systems thinking, as practice, and systems theory, as both its reflection and its general(ized) background, are badly needed for information systems to provide real information rather than misinformation. 


\section{Information Management Aspect of Innovative Processes}

\section{(The Dialectical) Systems Theory and Informing}

Systems thinking is a practice, as old as humankind, but limited to successful persons and groups only: it has always been a (formal or informal) basis of the requisite holism. This is to say, that the successful ones have happened or planned and managed to consider everything essential. The most essential oversights may have always have (had) to do with interdependencies.

(Beyond four millenia ago, Chinese philosophy reflected the need for thinking of interdependencies by its notion of "yin-yang". Antique Greek philosophy did the same by the notion of dialectics. It is not clear how much did the first authors of systems theory know about them or about the more contemporary authors on philosophy of dialectics such as Hegel (idealistic dialectics) and Engels (materialistic dialectics). See: e.g. Mulej et al., 2000, and references cited there.)

A similar attempt was suggested by L. von Bertalanffy, the author of the General Systems Theory (Bertalanffy, 1968, edition 1979) who urged mankind to think of the entire biosphere of the planet Earth as an organization that is an entity full of interdependences that partly support and partly fight each other. (Many thanks to Elohim who rediscovered that. (Elohim, 1998, Elohim, 1999, Elohim, 2000)) His requirement came to be found too demanding for most specialists, and they tried to use his principles inside their own disciplines, mostly, rather than to build bridges toward interdisciplinarity.

Thus, there is no chance any more to speak realistically of a General Systems Theory trying to achieve holism by bringing all real life features to a common denominator. This attempt makes their contents disappear too much, mathematical formalities may remain alone and lonely, saying very little about the complex and very complex reallife events and processes and ways of mastering them, instead of supporting wholism. Thus, over last three decades a set of different systems theories have developed covering different topics and aspects of the real life. (Francois 1992; Delgado, Banathy, eds., 1993; Mulej et al., 2000). Here we are not elaborating this topic, we have only introduced the path toward our own Dialectical Systems Theory (=DST) (Mulej 1976; Mulej 1979; Mulej et al. 1992; Mulej et al. 2000; Mulej, 2000).

DST is a version of systems thinking aimed at covering the topic of achievement of (a relative) holism by creative work and co-operation. Achievement of holism was very much the original aim of the founders of the General Systems Theory. But their way toward this important aim has proven limited in scope, it was supposed to be made of isomorphisms. If all aspects and relations of reality and all scientific disciplines are supposed to be covered by the same categories as isomorphisms, they must be very general. This brings us to mathematics and philosophy as two most general scientific disciplines.

Mathematics is a very good tool of generalization as long as we all understand its contents equally. The consequence of this fact as well as of the natural modern specialization of knowledge, field of work, and interest is a limitation of application of the (general?) systems thinking to single discipline/s and viewpoint/s, only. What results, is more or less a mathematical formality and - in terms of contents of the system - a fictitious holism, hence a danger of a serious oversimplification: a single specialization / viewpoint can cover only a limited fragment of the really existing complex of all characteristics of the object (feature, event, process) under consideration.

This means that a system of viewpoints is needed to bring observers / managers toward holism. All viewpoints linked into a system might be an ideal way, but it cannot be done. Therefore, we introduced the notion of the dialectical system that is a system of all and only essential viewpoints. There are several consequences reflected in this finding such as:

- The same reality can be seen differently from different viewpoints. Therefore they must be linked because they provide for partial insights which may be precious, but must be linked into a common synergy to be so indeed.

- The selection of viewpoints is crucial, critical. All further processes of observation, analysis, management, and action depend on it.

- In modern circumstances and conditions, it is essential to provide for the selection of viewpoints, which may be able to guide the observers, analysts, managers, actors toward holism and toward creativity. And creativity is to be employed toward innovativeness, innovating and innovation leading toward excellence, and thus toward competitiveness and ability to survive, i.e. viability. (According to the "viable systems theory" by Stafford Beer, viability is the capacity of an entity to survive and maintain its identity in a threatening environment. (see eg. Espejo, in Mulej et al., 2000).)

- The viewpoint selected is information, i.e. an influential and sometimes new message on which all steps following later-on in the work process depend.

- Selection of viewpoint/s is an information process. 


\section{Mulej and Zenko}

- The information process producing the viewpoint/s (or their system, possibly a dialectical system) can and must be managed for the aim (i.e. viability) to be attainable more smoothly or even at all.

Therefore, one of the components of the DST as a dialectical system is its law of hierarchy of succession and interdependence; it says /employs the finding that the earlier phases of a process are more influential than the next ones, which follow later, and they are all interdependent as are features showing up in them, too. In the case of human work, DST has its notion of objective and subjective starting points and interdependence of both of them as subsystems. (This means that we refuse both extremes of thinkers about thinking, i.e. the ones claiming that everything is and must be seen as an objective reality only allowing for no role or even impact of the human factor over the reality and its comprehension, on one hand, and the ones claiming that everything exists subjectively only, on the other extreme hand. Both exist, the objective and the subjective components of the reality around us and inside us.) The following conclusions surface:

- The objective starting points are made of interdependent needs and possibilities.

- The subjective starting points are made of interdependent values/emotions and knowledge (on both contents and methods).

- Selection of viewpoints depends on subjective starting points.

- Perception of needs and possibilities depends on viewpoint/s selected.

- Definition of preferential needs and corresponding possibilities depends on one's perception of needs and possibilities and on their interdependence.

- Definition of objectives depends on definition of preferential needs and corresponding possibilities and on their interdependence.

- Tasks definition, then their procedures definition, and then their work processes implementation depend on objectives definition.

- Final results depend, thus, on objective and subjective starting points (and the entire process taking place between the starting points definition and the results coming out).

- It is information that is both an essential input and an essential output of every step in this process.
- Both interdependence of needs for, and possibilities, of innovation, and their acceptance in subjective starting points are a precondition for final results to be innovative and therefore to have a chance to be viable / prosper in the modern innovative society and its economy.

- Dependence of the said acceptance on information received and perceived by decision-making persons (of any level in the organizational hierarchy).

As a real-life case clarifying this brief and condensed expression, let us take the real life in an organization:

- The entire span of the objective (i.e. really existing) needs and possibilities exist out there in the market and in here in the organization, but many may fail to be perceived.

- The organization is supposed to understand and master this reality as holistically as possible in order to be viable.

- Therefore, its top management try to do their best to think in a dialectical-systems concept. (Hopefully, no formal knowledge of the Dialectical Systems Theory is needed for the thinking in general to be in its style. Our experience demonstrates, after beyond ten thousand real-life cases worked on by our students over 30 years, that only few persons are capable of a DST style of thinking by nature; most humans are narrow under the pressure of their specialised education and monistic ideology, be it religious or political.) They do so by working as a team made of representatives of all business functions who are, hopefully, willing and able to co-operate creatively, to understand and accept that their views and viewpoints differ on the basis of their specialization due to the organizational division of work, and thus enable a common synergy if their different contributions are integrated rather than overruled.

- Once an individual member of the management team returns to his of her office, s/he tends to think and act from the viewpoint of his or her sectorial specialization, right and duty. What now comes into their new dialectical system is closed inside this specialization only. (In theoretical terms, it still may be called a Dialectical System, if it includes every viewpoint that is found essential and related to other essential viewpoints. What is essential depends on the decision. That's why the subjective starting points are crucial, and that's why it is so important that the subjective starting points are well related to the objective ones, so to be realistic enough.) The single 


\section{Information Management Aspect of Innovative Processes}

viewpoint selected causes a different part of the real characteristics to be perceived e.g. in marketing or in technical maintenance offices of the same organization.

- Inside these perceptions the preferential needs which are to be given priority over the others (e.g. inside a given sector/office), are selected, and so are the possibilities found suitable, corresponding to the preferential needs; e.g. finding new markets instead of the lost ones, in marketing.

- Operational objectives are set, on this basis, aimed at meeting the preferential needs by use of the corresponding possibilities, e.g. making a thorough market research in a country with which the organization has not been doing business so far.

- Definition of tasks follows and tells the sector's boss's subordinates what are they supposed to do, e.g. for the decided market research to be done and done well enough. (Hopefully, the definition of objectives and tasks happen in a rather democratic way, giving every co-worker a chance for his of her professional opinion to be expressed and confronted with other professional opinions. A holistic enough synergy is supposed to result more probably under such conditions than under the centocratic managerial style "The boss thinks, the others work.")

- Every task has to be studied in advance from the viewpoint of its processes and procedures, including the boss's task of co-ordination of individual processes toward their synergy.

- Once all the processes have been done well enough, on this basis, the final result can be attained.

Now, let us come to the information management aspect of the process sketched above. What links all the interdependent parts of the same steps in the process sketched above, as well as all the steps that follow each other? Data transformed to messages and further on to information, of course. Information enters each phase as a precondition for the phase to be done. And information leaves the phase as the carrier of its impact over the next phase. As soon as the information is not holistic enough (which depends on information requirement of the information recipient, and on the emitter's information quality, of course) it can easily be misinformation, i.e. an information causing unplanned consequences and diminishing the recipient's capacity to meet his or her tasks / needs.

Conclusion: Throughout the management, information, and basic processes there is a permanent need for information of a good enough (i.e. requisite) quality for the daily routine, and even more so for innovating to flourish, for innovations to result, and for viability to be achieved on this basis. If the starting points, in all their five elements and their linking into a synergetic dialectical system, are not holistic and innovation friendly rather than routinism friendly, the information in virtually any phase can hardly be good enough. (see: Green Paper, 1995; Green Paper, 1996) (There are more attributes of DST, but there is no room for us to discuss them here. See in English: Mulej, 2000.)

In addition, information system/s may belong to the most differently defined professional terms of our time: there are so many viewpoints for different professions to look at them, e.g.:

- engineering concerned with hard-ware,

- engineering concerned with soft-ware,

- libraries from several engineering viewpoints,

- libraries from the viewpoints of their contents,

- book keeping from several engineering viewpoints,

- book keeping from the viewpoints of their contents,

- marketing information systems,

- organizng,

- journalism,

What do they have in common? From our viewpoint, the answer reads: information is an impacting message of any form, which supports human work, especially creativity (in general, i.e. for very different ends) and innovativeness (if creativity is successfully applied to business or other economic goals or other goals covering benefit).

Hence, from the viewpoint of a business system (i.e. a system which is used to consider an enterprise or another organization from the viewpoint of production and other parts/kinds of business), information system management is a means to support and/or increase the human creativity, inventiveness and innovativeness, which will finally result in a better competitiveness and a better life of persons involved. - Solving the engineering problems is only a part of such a concept, they are not the only obstacles to a better life.

From such a viewpoint, the information process is no entity of its own (to be considered as a system) neither a rather independent part of a larger entity (to be considered as a subsystem), but an activity showing up in all other activities, and is hence better considered as a partial system (Potocan, 1999 etc., and others). 


\section{Innovativeness, Innovative Business and Their Information Aspect}

An information system is, if the business system is considered more holistically, one of its three (partial) subsystems: the basic, the management, and the information one (plus their environments, of course). (We should not forget about their synergies as well. On this basis, Mulej and Kajzer defined a dialectical system of four times ten guidelines (see: Mulej et al., 1994).) It is interdependent with the others. Even more, if the business system is modeled as a process or as an organizational hierarchy, the information (partial) system/flow is the one, which links all the others into an entity: all outputs and inputs of every phase or unit have the form of information, or at least are accompanied by an information. That is why it makes more sense if one speaks of the information aspect of the business system (Kajzer, 1987; Kajzer, 1992; Kajzer, Mulej, Marn, 1995).

Information, by definition, is that message, which brings to the recipient something new and influential. Hence, it is very near to innovation, from the recipient's viewpoint.

This is especially true when the circumstances of e.g. doing business change from the producers market ones (in which the supply is smaller than the demand and everything can be sold, the producers dominate over the customers) to the buyers market ones. In the first case (older in history), innovation is not needed, and it even makes no sense to invest into the invention-innovation process, at least not from the viewpoint of a short-term perspective of economic rationality and resources productivity. Now, in the buyers market, information is becoming a much more essential source of the ability to produce invention, potential innovation and innovation, to compete and to be viable. It has no longer only to be an influential and new message, it must also enable its recipients to produce novelty which makes sense and benefit to its user, i.e. it must support innovation management which is innovative. (To meet this end, information must be quite holistic, and hence grounded in systemic thinking, obviously. Otherwise, data and messages would not become benefitial informations, but detrimental misinformation. They would support or even cause wrong decisions and actions, leading to failure and even realization of entropy, e.g. in the form of bankruptcy, ecological problems, etc.)

\section{Guidelines on Preconditions for a Business to be Innovative Revisited}

Years ago, Mulej and Kajzer (see: Mulej et al., 1994) found that it is not enough if one is aware of existence of the basic, management and information processes, rather than

\section{Mulej and Zenko}

only of the basic one. Then they found, that all three processes may, in terms of their contents and of the values expressed by their authors, be supportive either of the rather routinized ways of working and living or of rather innovative ones. They formulated guidelines expressing preconditions for all three processes as well as their synergies to support innovation rather than routinism. Here we will reproduce only the part dealing with information (partial) subsystem. We lack room for all of them.

\section{System of Ten Preconditions for Innovativeness Of Information (Partial) System of Business}

The information is the impacting input (= basis) as well as output (= means) of management. It must support and clearly express the identity of the organization as one with an innovative rather than routinized business. Hence the ten guidelines read:

1. Purpose of the innovative business is the highest possible effectiveness, not only efficiency; the information (partial) system supports it.

2. Goal of the information process is solving real problems.

3. Information process is directed towards creativity, inventiveness and innovativeness.

4. Essence of informing is strengthening and supporting the creativity, inventiveness, potential innovativeness and innovativeness.

5. Co-operative management style is a precondition for the co-workers to be informed and creative.

6. Knowledge of the information and innovation requirements.

7. Insight into the process and other characteristics of business.

8. Computer is a tool, not a replacement for creation and innovation processes.

9. Information aspect of the (innovative) business is a better approach than an information process or (partial) system.

10. Obstacles and resistance against novelties, including innovation are to be expected in the process of formation of the information (partial) system.

Our brief comments are organized along the numbers in P. 5 without repeating the guideline's formulation. 


\section{Information Management Aspect of Innovative Processes}

Ad 5.1: The effectiveness of business is screened in the quality of life, no way only in the products quantity and even less so in the quantity of permanently equal products and services. The information process supports the realization of such a purpose by providing the right information to the right person at the right place and in the right time. (This requirement is a lot easier to express than to meet, of course. It requires a lot of systemic thinking, again.)

Ad 5.2: If the purpose is what we said right now, then it is very important that the information system supplies to the management and basic systems not just any kind of data, messages and information, but rather the ones which support solving real problems showing up in business and aggravating its effectiveness, and not fictitious problems. Dealing with fictitious problems would not be rational and would not provide information (but data only, most probably).

Ad 5.3: The information system consists of (1) discovering, (2) defining, and (3) solving the real problems, only then (4) the implementation of the solution follows. In course of the process the grade of freedom, i.e. of the choice between options, diminishes from step to step. It makes sense to consider such a logical organization of the process and to include creativity into every step of the process, as well as into observation of them with the intention to discover new real problems. This strengthens the efficiency of the information process and the effectiveness of the entire business.

Ad 5.4: In the process of decision making or another work it is necessary to know enough about the contents and methods, if we want the process to run creatively and produce effective results. Unless so, there will not be enough innovativeness. Hence, the essence of the information process is the support for and strengthening of creativity. The creative work represents creation of new information by use of information. Thus, one can say: innovation is information, not only a material product, data or message, because it impacts, by providing new insights and knowledge, the life practice (in a beneficial way, hopefully).

Ad 5.5: The described way of perception and solution of (the real!) problems crucially depends of its source of new insights - ideas, inventions, potential innovations and innovations. Therefore, the individuals and groups who know the work and its conditions and problems, must be granted encouragement, opportunity and need to perceive and solve problems. Such necessary circumstances tend to be lacking as long as the managers manage by ordering instead by co-operation.
Ad 5.6: For individuals and groups to deal with all the necessary activities and only with them, it is critical to define the information process as a deliberate search for, finding out and covering of the information requirements, and so at the same time also the innovation requirements. With them, an innovation process can be initiated and be sufficiently rational.

Ad 5.7: It is hard to know the information requirements, if there is no sufficiently clear insight into the process and other characteristics of business, its interdependencies and mutual impacts among its single components and with its environment. Namely, without such an insight it is hard to perceive problems and/or opportunities. There is quite some knowledge concerning this need around (see: Mulej et al., 1994; Mulej, 2000).

Ad 5.8: Many come to think of computer as quickly as they hear of the information process, informatics etc., rather than of fresh knowledge and new insights, i.e. new information. In reality, computer is only one of the tools which is important, but it can no way replace the human creativity, although it can support it. Let us not ignore that a better tool demands a more clever individual.

Ad 5.9: Since the information process links all parts of the business process and all its activities, we do not have to do, neither primarily nor only, with informing as an autonomous process. Such a view might include the rather engineering aspects of informing, which are important, too, of course, but they are not in the forefront here. That is why it is better to speak about the information aspect of e.g. business, than about an information process. Thus, it becomes clear, from the viewpoint selected here, that information serves an innovative business when business is based on flexibility of its organization and on sufficient trust by managers to their subordinates (supported by insights mentioned earlier); it is less so if the basis of business is a hard-systemic, bureaucratic organization which does not enable perception, and even less so the solving the problems, not to speak of changing the problems into opportunities.

Ad 5.10: Information must consider obstacles and oppositions to novelties, permanently, and take into account that the dilemma whether supports or obstacles will win in a concrete case, depends on the level of innovativeness of the culture (Gabrijelcic, 1995; Ivanko, 1993; Mesner Andolsek, 1995; Mulej et al., 1994; Ursic, Mulej, eds., 1996; Ursic, Pivka, 2000; Ovsenik, 1999; etc.). Therefore, the information process must, proactively, perceive and reflect as many as possible characteristics of the culture and of the potential oppositions and obstacles, 


\section{Mulej and Zenko}

and do so in time, for the management to have good grounds in preparation and taking of its measures.

Conclusion from the viewpoint of the title of this contribution: it is hardly possible to work on information management aspects of innovative processes well enough, if systems thinking is poorly applied.

Of course, such guidelines are to be considered on all levels of a company (or another organization) operation, the political and the operational one, the long-term and the short term one, the broader and the narrower one (in terms of their impacts). The political and the operational management are, both, just two components of the same system of running the business systems (Belak, Kajzer, 1995; Belak et al., eds, 1997; Belak, 2000, and earlier). They have, both, the same purpose - to increase the effectiveness in terms of the quality of life (for which the business rentability on the basis of competitiveness is one of the sources).

These guidelines, and their dependence on systemic thinking, also let us see that is a dangerous simplification, if one expects the computer based technology, called the information technology, to seriously help the less developed/advanced countries/regions/peoples to quickly catch up with the most advanced minority of the world (see: Bucar, 1999; Dyck, Mulej, and coauthors, 1998). Too much depends on the roots of the management style (see: Zenko, 1999 a,b; etc.).

\section{Some Conclusions}

It is very necessary to consider the information system development quite holistically. Many viewpoints are very important, of course, in general, including their relations and resulting/emerging synergies. That's why the footnote 19 applies all the time. In the current situation of e.g. CEE countries, it is essential for them to become innovative societies and hence to have their basis in the prevalence of the innovative business over the routinized one in their organizations as business systems. In such a perspective, the information system must support the development of typical innovative characteristics of the business systems and other organizations. The guidelines briefed here, may help quite a bit. On their basis, the information system is considered as a partial system inside the business system which is dialectical, fuzzy, soft and flexible (Mulej et al., 1992; Mulej et al., 2000). It is a task of the information management of the modern, ie. Innovative business and its processes to be very careful in this respect, in the name of the entire organizational management and of the organization's viability. This means that the information management problem is very much a problem of the subjective starting points of the observers / researcher / managers of the entire business process, be it an innovative or a routinised one.

\section{References}

BELAK, J., KAJZER, Š., eds. (1995): Unternehmen im Übergangsprozeß zur Marktwirtschaft - mit Beispielen aus Slowenien. Linde Verlag, Wien

BELAK, J., et al. (2000): Podjetništvo, politika podjetja in management (Entrepreneurship, Enterprise Policy and Management. In Slovene. 4th edition). MER, Gubno

BELAK, J., et al. (Eds) (1997): Unternehmensentwicklung und Management. Versus Verlag, Zurich, $\mathrm{CH}$

BERTALANFFY, L. von (1968, ed. 1979): Genaral Systems theory. Brazzilier, New York

BUCAR, M. (1999): Tehnolosko prestrukturiranje podjetij v drzavah v tranziciji z vidika informacijskih tehnologij. Dr. Diss., University of Maribor, Maribor

CREECH, B. (1994): The Five Pillars of TQM. How to Make Total Quality Work for You. Truman, New York

DELGADO, R. R., BANATHY, B. H. (1993): International Systems Science Handbook. Systemic Publications, Madrid

DYCK, R., MULEJ, M., and coauthors (1998): Self-Transformation of the Forgotten Four-Fifths. Kendall/Hunt, Dubuque, Iowa

ELOHIM (1999): A Message from prof. Elohim. Poster. 10th WOSC Conference, Uxbridge

ELOHIM (2000): Business based of Bertalanffy's Weltanschauung: A renewed entrepreneurship spirit is urgenttly needed. In. Rebernik, M., Mulej, M., eds: STIQE 2000. Institute for Systems Research Maribor

FRANCOIS, Ch. (1992): Diccionario de Teoria General de Sistemas y Cibernetica. Conceptos y Terminos. Editado por GESI Asocialicion Argentina de Teoria General de Sistemas y Cibernetica, Buenos Aires, Argentina

GABRIJELCIC, J. (1995): Od kakovosti k odlicnosti. Po poti organizacijskega razvoja (From Quality to Excellence. By Organizational Development. In Slovene). Dolenjska zalozba Novo Mesto

IVANKO, Š., et al. (1993): Osnove organiziranja poslovanja in dela (Basics of Organizing of Business and Work. In Slovene). UM, Ekonomsko-poslovna fakulteta, Maribor

KAJZER, Š. (1987): Kibernetika ekonomskih sistemov (Cybernetics of Business Systems. In Slovene). UM, Ekonomsko-poslovna fakulteta, Maribor,

KAJZER, Š., ed., Informacijski vidik inovativnega poslovanja (The Information Aspect of an Innovative Business. In Slovene). Naše gospodarstvo (Maribor) 38(1992)1-2

KAJZER, Š., MULEJ, M., MARN, F. (1995): The Process Approach to Business as a Well Proven Tool of Maintaining Cybernetics in Business Management. Systemica

.. Green Paper on Innovation. EU 1995. www 


\section{Information Management Aspect of Innovative Processes}

.. Green Paper on Living in an Information Society: People First. EU 1996. www

MESNER-ANDOLŠEK, D. (1995) Organizacijska kultura (Organizational Culture. In Slovene). Gospodarski vestnik Ljubljana

MULEJ, M. (1976): Towards the Dialectical Systems Theory. In: Trappl, R., ed., Progress in Cybernetics and Systems Research, vol. 5, Proceedings of EMCSR 1976, Vienna, Austria

MULEJ, M., et al. (1992): Teorije sistemov (Systems Theories. In Slovene). UM, Ekonomsko-poslovna fakulteta, Maribor

MULEJ, M. (1979): Ustvarjalno delo in dialekticna teorija sistemov (Creative Work and thew Dialectical Systems Theory): Razvojni center Celje, Slovenia (Yugoslavia then)

MULEJ, M., et al. (1994): Inovacijski management. Prvi del, Inoviranje managementa (Innovation Management. Part I, Innovation of Management. In Slovene). UM, Ekonomsko-poslovna fakulteta, Maribor, 1994 (TEMPUS Joint European Project 3076)

MULEJ, M. (2000): Basics OF Systems Thinking (Applied to Innovation Management). UM, Faculty of Economics and Business, International Program FEBA, Maribor

MULEJ, M., in drugi (2000): Dialekticna in druge mehkosistemske teorije (podlaga za celovitost in uspeh managementa). (The dialectical and other soft systems theories - a basis for wholism and success of management. In Slovene). UM, Ekonomsko-poslovna fakulteta, Maribor

MULEJ, M., KAJZER, S. (1998): Ethics of interpedendence and the law of requisite holism. In: Rebernik, M., Mulej, M., eds.: STIQE '98. Institute for Systems Research et al., Maribor

OVSENIK, J. (1999): Stebri nove doktrine organizacije, managementa in organizacijskega obnašanja. (Pillars of a new doctrine of organization, management and organizational behavior. In Slovene). UM, Fakulteta za organizacijske vede, Kranj

POTOCAN, V. (1998): Holistic decision making as a practicle example of Training for Systems Thinking. In: Hofer, S., Doucek, P., eds. (1999): IDIMT '98. Universitaetsverlag Rudolf Trauner, Linz
POTOCAN, V. (1999): Sistem standardnih odlocitvenih procesov v podjetju. Dr. Diss., University of Maribor, Maribor

REBERNIK, M., MULEJ, M. (2000): Requisite holism, isolating mechanism and entrepreneurship. Kybernetes, Vol. 29, no 9/10, pp. $1126-1140$

URSIC, D., MULEJ, J., eds. (1996): Zbornik clankov na osnovi 16. PODIM "Inoviranje, kakovost in certifikati ISO 9000. (Articles based on 16th Innovation Conference "PODIM 95" - Innovation, Quality and ISO 9000 Certificate. In Slovene). In: Nase gospodarstvo (Maribor) 42(1996) 1-2

UNESCO Glasnik of October, 1999, November, 1999, March, 2000, December, 2000, several articles (N.B. Slovenian edition of UNESCO Courier)

URSIC, D., PIVKA, M. (2000): Management concepts transformation in Slovenia. Management (Split), vol. 5, no 2, pp 19-34

WOOD, R. (2000): Managing Complexity. How Business can adapt and prosper in the connected economy. The Economist Books, London, etc.

ZENKO, Z. (1999): Comparative Analysis of Management Models of Japan, USA, and Europe. Dr. Diss. University of Maribor, Maribor

ZENKO, Z., MULEJ, M. (1999): Participative Management in Japan, USA and Europe. Systemica, 12 (in press)

\section{BIOGRAPHIES}

Matjaz Mulej, 1941, professor of Systems and innovation theory, faculty of economics and business, University of Maribor, Maribor, Slovenia. Author of the Dialectical Systems Theory. Publications in 28 countries, 10 visiting professorships, about 40 books and proceedings, etc.

Zdenka Zenko, 1962, associate professor in Systems Theory and Management. Used to work in several companies in Slovenia and USA before joining University in Maribor in Nov. 2000. 